\author{
Klaudia Przybysz \\ Wrocław University of Economics \\ e-mail: klaudia.przybysz@ue.wroc.pl
}

\title{
LIFELONG LEARNING IDEA AGAINST THE BACKGROUND OF POLES' NEEDS
}

\begin{abstract}
Summary: The rate of economic changes and the aging of the population made it necessary to give priority to the importance of lifelong learning (see for example the Lisbon Strategy). The conducted study concerned the demand on courses, trainings and certifications in Poland. This article aims to analyze the educational needs reported by respondents who are in the production age. Our study contains the classification based on sex, education level, type of occupation in relation to whether respondents declare such needs. The research also included the type of courses undertaken and their assessment with respect to the usefulness for further professional life. The proposed approach to this issue may be a substructure of a multidimensional analysis of the situation on the labour market and it may help to identify the factors determining the attractiveness of potential employees from the perspective of employers' needs.
\end{abstract}

Keywords: lifelong learning, multidimensional analysis, labour market.

DOI: $10.15611 /$ ekt.2014.3.03

\section{Introduction}

The rate of economic changes and the aging of the population made it necessary to give priority to the importance of lifelong learning (see for example the Lisbon Strategy). The conducted study concerned the demand on courses, trainings and certifications in Poland. This issue seems so important because, in comparison with other EU countries, Poles to a small extent participate in courses and trainings improving their qualifications (see Figure 1). The highest percentage of people participating in trainings is in Denmark - over 30\%. The worst situation is in the countries in the south-eastern area of the European Union. There the percentage of people improving their qualifications is lower than $3.2 \%$. In Poland only $4.5 \%$ of the population of the working age attended courses and trainings. Some reasons for this attitude of Poles are known - for example, the fact that employers are unwilling to share the costs of trainings. However, other studies show that as the main reason for the lack of interest 


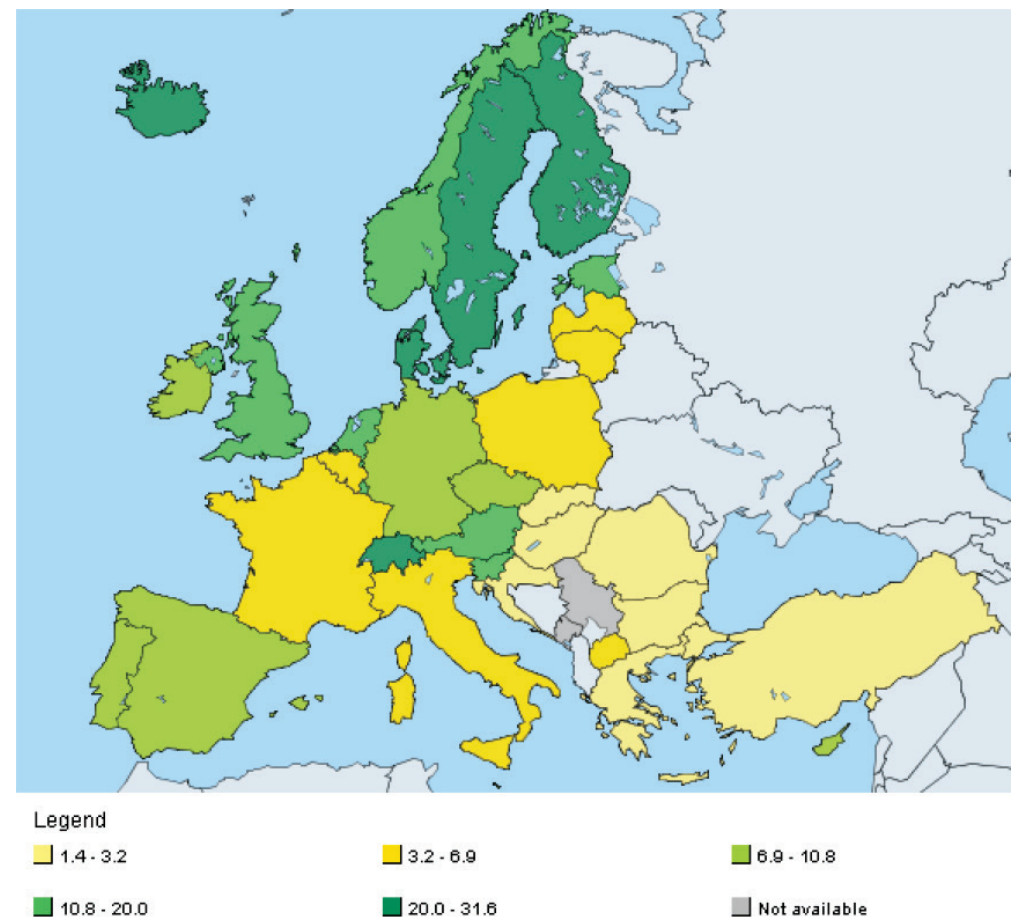

Figure 1. Lifelong learning in Europe in 2012 (refers to persons aged 25 to 64) (in \%)

Source: Eurostat Data.

in courses Poles indicate a lack of motivation and time - not money. Confirmation that the one of the main barriers to undertake the training is the lack of time could be the fact of the ever-increasing popularity of the universities of the third age among persons in the retirement age (see for example: [Przybysz, Dziechciarz-Duda 2011]). However, this article aims to analyze the educational needs reported by respondents who are in the production age. Our study contains the classification based on sex, education level, type of occupation in relation to whether respondents declare such needs. The research also included the type of courses undertaken and their assessment with respect to the usefulness for further professional life. The proposed approach to this issue may be a substructure of a multidimensional analysis of the situation on the labour market and it may help to identify the factors determining the attractiveness of potential employees from the perspective of employers' needs.

\section{The lifelong learning idea}

Rapidly developing technologies and the necessity to meet the requirements of the evolving labour market mean that the idea of lifelong learning is worth dissemination. 
This applies not only to people already employed who want to develop and invest in their skills for the future to cope with the competitiveness on the job market. It is also particularly important for people looking for a job who do not have any professional experience and those forced to retrain to find employment because of the situation on the labour market. For the employers not only experience and qualifications of the employees are important but also the desire to develop, orientation on acquiring new knowledge and the ability to adapt to constantly changing conditions on the job market. It should be noted that the lifelong learning idea in the context of aging societies of the UE is an important development factor. Society in the European Union is getting older. According to the European Commission in 2050, the number of people over 65 will rise by $70 \%$ and older than 80 - up to $170 \%$ (http://ec.europa. eu/index_pl.htm). Lifelong learning is one of the priorities of the educational policy in the European Union and its foundation is focused on guaranteeing Europeans learning opportunities throughout their lives, such as the pre-stage to late retirement.

The Lisbon Strategy defines the concept of lifelong learning as "all activities related to learning throughout life, in order that improve the level of knowledge, skills and competences in the personal, civic, social and/or employment-related term." In 2002 the European Council meeting in Barcelona decided that education is a factor of economic growth, research and innovation, competitiveness maintaining the level of employment, social cohesion and active citizenship.

Therefore, the set of the factors of demand on educational services for adults is not limited to the fact of aging. This demand is also shaped by the impact of factors such as:

- not employment related economic development model - increased competition on the labour market,

- the development of technology causing changes in the structure of labour demand - increasing demand for workers with higher levels of education,

- increasing awareness of the value of education,

- the growing share of flexible forms of employment - EU priorities,

- the lengthening of life expectancy and retirement age.

\section{The situation in Poland}

The labour market in Poland is an employer's market. This situation creates a need to match the profile of a potential employee to employer's needs at all stages:

- education: profiles of education focused on employer's needs,

- employment: competences and qualifications of employees (There is a difference between the concept of competencies and qualifications. Competence should be understood as knowledge, skills and attitudes associated with the performance of specific actions, independent of the mode in which they were acquired, and whether they have been corroborated with a validation procedure and the qualifications, being verified competencies, are understood as knowledge, skills, 
and attitudes that have been corroborated in the process of a formal validation procedure (by an evaluating unit accredited by public authorities)),

- the time of unemployment - improve or changing the qualifications of unemployed.

Research studies shows (see: [Study of Human Capital... 2013]) that the requirements of employers are the reflection of the changes taking place on the labour market. So not only experience and education but also the willingness to a flexible approach and improvement of qualifications are important to employers. This situation indicates the best profile of potential employee, who:

- meets the expectations of an employer;

- adapts to changes in demand on the labour market,

- is ready to change his or her qualifications,

- is willing to train (best at their own expense)

- may have qualifications for more than one occupation.

Numerous studies confirm that there is a positive correlation between the level of education as well as professional qualifications and success on the labour market. This professional prosperity and well-being may be related both in the material and non-economic areas of life (see: [Dziechciarz 2011; Król, Dziechciarz-Duda 2012; Król, Dziechciarz-Duda 2013]). However, the Study of Human Capital in Poland (BKL) conducted in 2013 indicates a weak interest of Poles in the idea of learning across the life span:

- more than $64 \%$ of Poles did not increase their competence in any kind of courses in last year,

- among the currently employed $28 \%$ had never participated in courses, training courses, among the unemployed $-44 \%$, and among the economically inactive $-52 \%$,

- most of the $80 \%$ of Poles who last year did not improve their competence and participated in training courses as a reason for the lack of activity in this area points to the lack of a need to improve their professional competence, lack of time or motivation.

\section{The study}

The aim of the study was to examine how Poles react to signals from the labour market. Why do they not like to take part in various courses and trainings improving their qualifications? It was assumed that it is possible to lead to the identification of segments by using the method of classification, so that one can identify the profiles of people on the basis of the reasons for which they attended or they would like to start training. The results of such classification could contribute to the creation of offers of training specifically targeted to people interested in developing their own careers. This issue seems very important due to the fact that the offer of trainings fitted to the current needs can bring the effect of an increased number of participants. 
The Data. The Study of Human Capital in Poland ${ }^{1}$ is a Poland- and Europeunique project of monitoring of the Polish labour market. Polish Agency for Enterprise Development (PARP) in collaboration with the Jagiellonian University will follow the changes of structure and demand for competencies on the labour market until 2014:

- over 16000 employers,

- over 17900 people of working age,

- over 8000 unemployed registered in labour offices,

- over 35700 students of upper secondary schools,

- over 33000 students of institutions of higher education,

- over 20000 job offers,

- over 4500 training institutions.

The method. In the study the classification trees were used with Exhausting CHAID as a tree construction algorithm. The minimum number of observations in the parent node was 100 and in the child nodes -50 . Maximum depth was 5 .

Nine classification trees were created. In each of them, dependent variable was a different reason for participate in a training:

- the development of one's own interests,

- willingness take a new job,

- certificate/diploma,

- gaining professional qualifications,

- meeting new people/pleasure,

- retraining/changing professional skills,

- improving skills needed in one's present job,

- to reduce the risk of job loss,

- free participation.

In each tree as independent variables the demographics data were used:

- age,

- sex,

- employment status,

- type of education,

- family status,

- level of income,

- work experience.

Each time the same set of dependent variables was used, but in combination with the various independent variables they have a different power of discrimination. Therefore, the demographic variables not always "belonged" to the tree in the same set.

Only those trees which meet requirements of prediction quality (approximately $85 \%$ ) will be shown and discussed. Each time conclusions were formulated only after

\footnotetext{
${ }^{1}$ BKL - www.bkl.parp.gov.pl.
} 
an assessment of the stability of the trees according to the requirements described by Breiman, Friedman, Olshen [1984].

\section{The results}

The first of the nine created trees uses a variable: reason for the training - the development of one's own interests. You may have noticed that people who participated or intend to participate in courses because of the development of their own interests are divided into two groups: students (Figure 2, node 1 - part of the tree on the left side) and women (node 19 in Figure 2 - on the right side).
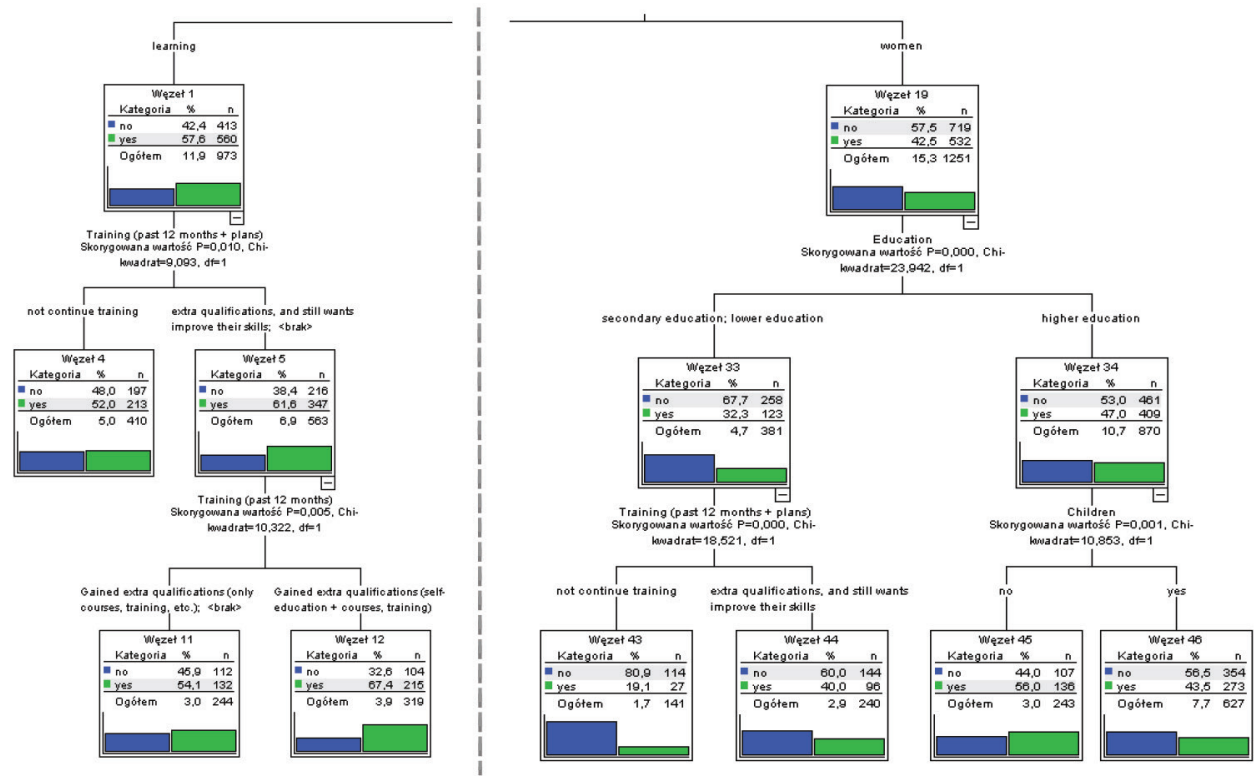

Figure 2. Parts of the classification tree - dependent variable: the development of one's own interests (nodes 1 and 19)

Source: own calculations based on the data from BKL.

Students seem to be very well aware of the importance of qualifications and, comparing to the whole population, they more often participate in trainings. More than half of them participated in a training or course in the last year and, more importantly, they still want to train. They declared willingness to participate in courses and self-study. On the other hand, in Figure 1 women with lower and secondary education level are positioned. They participated in courses in the last year, and $40 \%$ would like to start a training in the future. Women with a higher education level are more likely to improve their education, more often than those who do not have children. 
Figure 3 shows a part of tree (node number 4) constructed with dependent variable reason for the training - the willingness take a new job. Identified segment is formed mostly by the unemployed and housewives. They are the most motivated respondents. Both groups in the majority (near $80 \%$ ) declare the willingness to improve their skills.

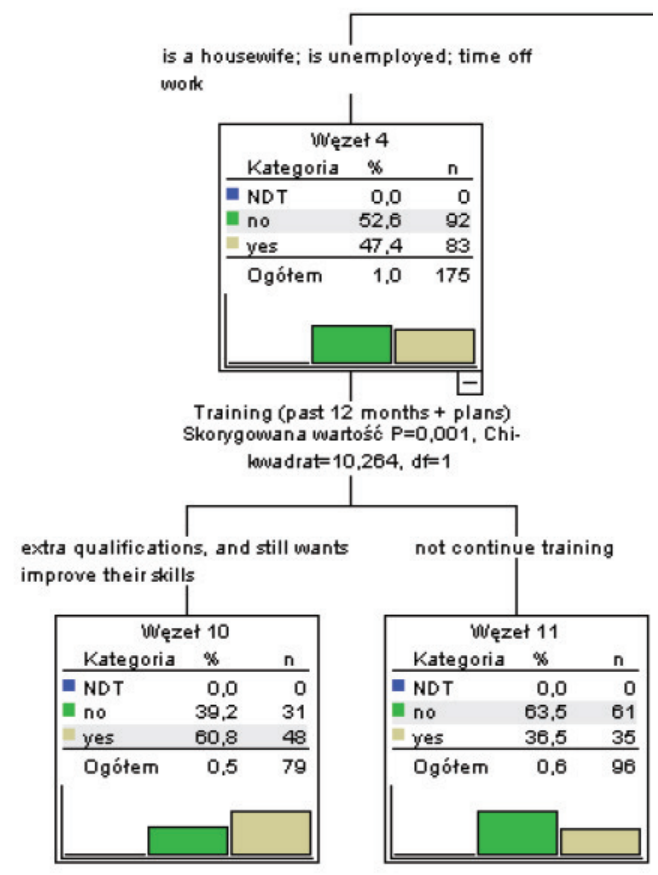

Figure 3. Parts of the classification tree - dependent variable: reason for the training: the willingness take a new job

Source: own calculations based on the data from BKL.

Figure 4 shows part of the tree that was created by means of a variable reason for training: improvement of professional skills. Nodes from 22 to 24 well illustrate the importance of the age of a respondent with respect to the development of professional skills. Probably a desire to lifelong learning increases with age. Moreover, a higher salary is also positively correlated with the willingness to training.

An unexpected situation can be observed looking at the tree that have been created on the basis of reasons which can be considered as important from the point of view of maintaining of a current job - reason for training: to reduce the risk of job loss (see Figure 5). Respondents who already employed were first divided in regard to the experience (expressed in years of work), then to the average monthly wage, sex and education level. As visible in all created nodes, the majority of classified 


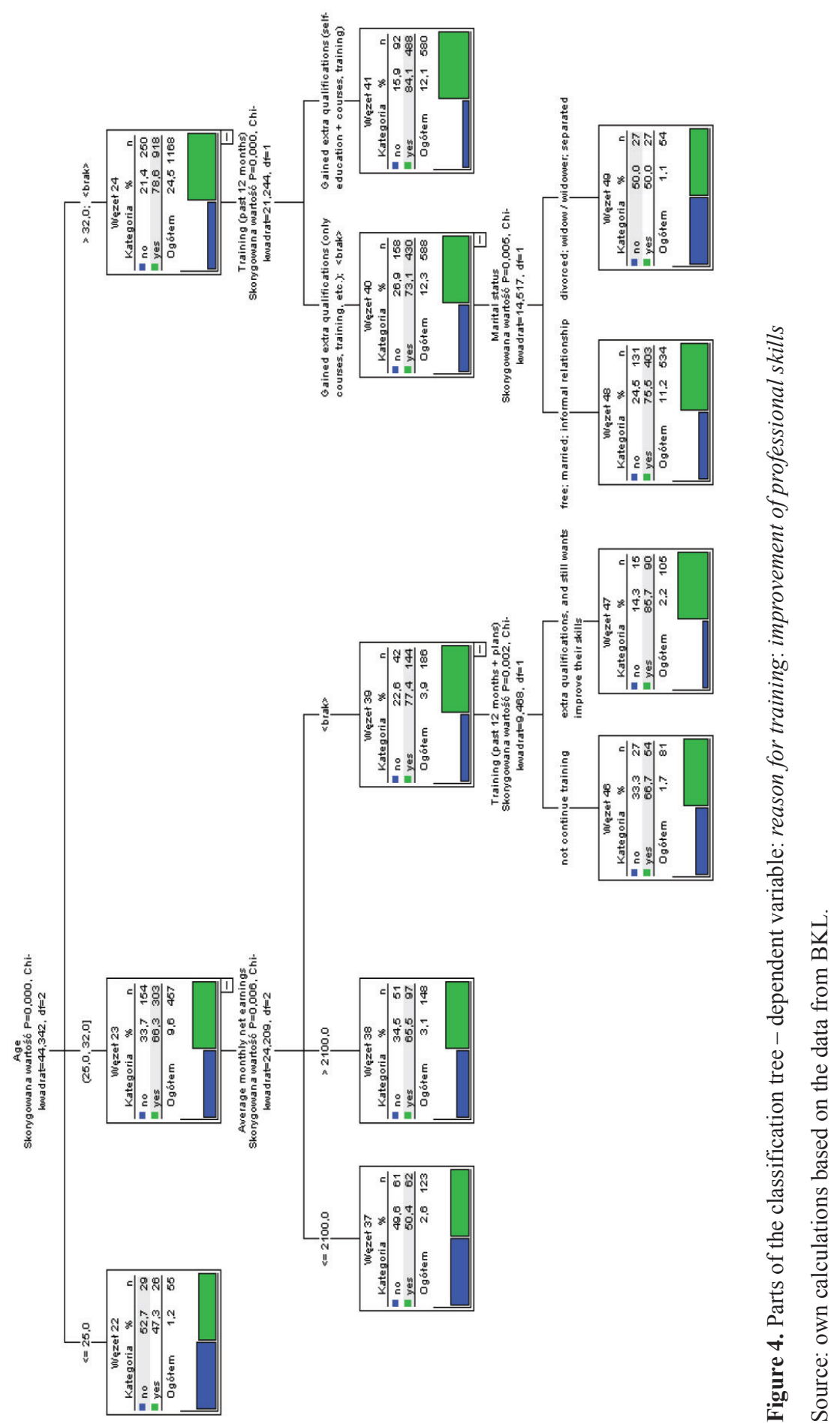




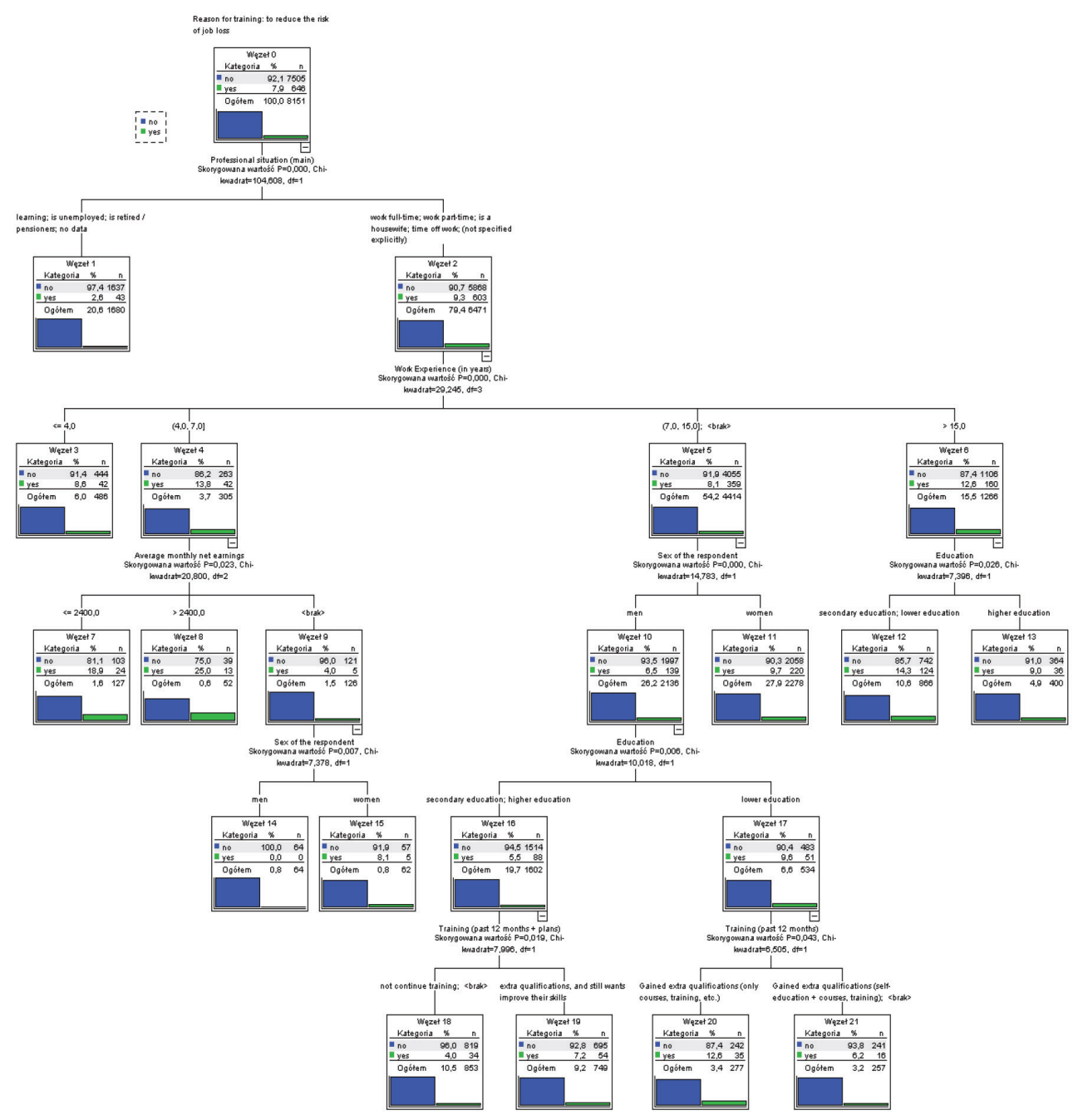

Figure 5. Classification tree - dependent variable: reason for training: to reduce the risk of job loss Source: own calculations based on the data from BKL.

people (about 90\%), declared lack of a desire to participate in courses and trainings for the reason: reduce the risk of job loss.

\section{Summing-up}

The use of classification trees resulted in the separation of several groups of respondents. The first one (see Figure 3) includes those who are not active on the 
labour market, in particular unemployed or women remaining so far at home for various reasons. This is a segment of people who are very motivated to improve their education. It can be concluded that they believe that the participation in courses and trainings will improve their situation on the labour market and make it easier to find a job. An ideal offer for this group is courses organized by labour offices, preferably for free, with the possibility of obtaining certificates.

The second segment is also comprised of people inactive on the labour market. It consists of pupils and students (the left side of Figure 2). This is a group that appreciates the usefulness of courses and trainings in the future professional life. They declare willingness to continue learning and participate in trainings. The offer for this group may include courses leading to a certificate but probably more popular will be courses organized by institutions specialized in trainings, not labour offices. Trainings paid for by future employers will be certainly very attractive.

The third segment also appreciates the importance of lifelong learning (the right part of Figure 2). It consists mostly of women. Some of them have a need to get the next level of education and another part of them has already a university degree but sees a need for courses and trainings. As described earlier, women who do not have children are more willing to take courses. Perhaps it is worth mobilizing those women who have children through subsidies to courses and adjusting the hours of study to meet their needs.

The segment created by the tree number 4 consists of economically active people. Among them the propensity to use additional courses and trainings increases with age. It is worth noting that higher wages also affect on the declaration of willingness to further education. People in this segment will probably be interested in courses ending in certificates, which are highly valued by employers and which distinguish them on the labour market. In this case, the high price may be a mobilizing factor.

A particular group on the labour market is constituted by professionally active people, who are described by tree 5 . None of them are interested in trainings because of the fear of job loss. It is difficult to assess whether Poles are not afraid to lose their job or they believe that their situation on the labour market is so stable that there is no need for further education. It can be assumed that Poles are reluctant to training and change their qualifications due to the mentality shaped by the previous system. If so, the change could be expected at the time of the entry of younger and younger generations into the labour market.

\section{References}

Breiman L., Friedman J.H.,. Olshen R.A, Stone C.J., 1984, Classification and Regression Trees, Wadsworth, Belmont.

Dziechciarz J. et al., 1986, Ekonometria z elementami programowania matematycznego i analizy porównawczej; S. Bartosiewicz (ed.); AE Wrocław. 
Dziechciarz J., 1993, Ekonometryczne modelowanie procesów gospodarczych: modele ze zmiennymi i losowymi parametrami, AE Wrocław, Wrocław.

Dziechciarz J., Król A., Targaszewska M., 2014, Various approaches to measuring effectiveness of tertiary education, [in:] A. Geyer-Schulz, J. Pociecha (eds.), Proceedings of the Third Bilateral German-Polish Symposium on Data Analysis and Its Applications, KIT Press, Karlsruhe.

Dziechciarz J., 2011, On rate of return measurement in education, Ekonometria, no. 31, UE Wrocław, pp. 49-66.

Dziechciarz J., 1989, Changing and random coefficient models. A survey, [in:] Statistical Analysis and Forecasting of Economic Structural Change, Springer Berlin Heidelberg, pp. 217-251.

Eurostat, http://epp.eurostat.ec.europa.eu/portal/page/portal/statistics/themes [accessed: 12.2013].

Global Report on Adult Learning and Education, 2009, UNESCO Institute for Lifelong Learning, Hamburg.

Król A., Dziechciarz-Duda M., 2013, On the non-monetary benefits of tertiary education, Ekonometria, no. 3(41), UE Wrocław, pp. 78-94.

Król A., Dziechciarz-Duda M., 2012, Próba zastosowania modelu Mincera do oceny wpływu wyższego wykształcenia na poziom wynagrodzeń, Ekonometria, no. 3(37), UE Wrocław, pp. 56-69.

Przybysz K., Dziechciarz-Duda M., 2011, Rynek usług edukacyjnych dla osób starszych - analiza cech studentów uniwersytetów trzeciego wieku, [in:] J. Garczarczyk (ed.), Metody pomiaru i analizy rynku ustug. Pomiar jakościowy - zastosowania i efektywność, Zeszyty Naukowe no. 201, UE Poznań, pp. 44-55.

Qualifications and Lifelong Learning, 2007, Policy Brief. OECD Observer.

Study of Human Capital in Poland (BKL - Bilans Kapitału Ludzkiego), 2013, http://bkl.parp.gov.pl [accessed: 06.2013].

Wildowicz-Giegiel A., 2011, The Popularity of The Idea of Lifelong Learning in Polish Economy Against the Background of the EU-27 Countries, The 53th International Scientific Conference of Daugavpils University, Daugavpils.

\section{IDEA KSZTALCENIA USTAWICZNEGO NA TLE POTRZEB POLAKÓW}

Streszczenie: Tempo zmian gospodarczych i starzenie się ludności spowodowało konieczność uczenia się przez całe życie (Strategia Lizbońska). Przeprowadzone badania dotyczą popytu na kursy, szkolenia i certyfikacji w Polsce. Artykuł ma na celu analizę potrzeb edukacyjnych zgłaszanych przez respondentów w wieku produkcyjnym. Nasze badanie zawiera klasyfikację ze względu na płeć, wykształcenie, rodzaj zawodu w odniesieniu do deklarowanych potrzeb szkoleniowych. Badanie obejmowało również analizę rodzaju podejmowanych kursów oraz ocenę ich przydatności w dalszym życiu zawodowym. Proponowane podejście do analizowanego problemu może być podbudową do wielowymiarowej analizy sytuacji na rynku pracy i pomóc w identyfikacji czynników decydujących o atrakcyjności potencjalnych pracowników z punktu widzenia potrzeb pracodawców.

Słowa kluczowe: lifelong learning, wielowymiarowa analiza statystyczna, rynek pracy. 